\title{
The communicative dimension of landscape. A theoretical and applied proposal ${ }^{1}$
}

\author{
Joan Nogué2 \& Jordi de San Eugenio Vela ${ }^{3}$
}

\begin{abstract}
The fusion of knowledge, the interrelationship of disciplines and, finally, the interaction of learning fields, provides new challenges for an auto denominated global society. The contemporary value of landscape, linked to the patent commodification of culture, the commercial construction of identities, the triumph of inauthenticity, of the induced representation or the economy of symbolism, open up great prospects for studying the symbolic value of landscape. The rapprochement of geographical praxis to the study of space intangibles, linked to the discovery of emotional geographies, besides the growing interest of communicational sciences on the territorial discourse, allow us to envisage a communicative study of landscape based on a fusion of geographical and communicational knowledge. The balancing of the variables: geography, landscape, emotion and communication, enables the progress towards analysing the emotionalisation of space to discern its intangible value, which emerges from the application of different communication techniques.
\end{abstract}

Key words: Landscape, communication, territorial identity, branding, intangibles.

\section{RESUMEN}

La fusión del conocimiento, la interrelación de disciplinas y, en definitiva, la interacción de saberes proporcionan nuevos retos para una sociedad que se autodenomina global. El valor contemporáneo del paisaje, vinculado a una manifiesta mercantilización de la cultura, la construcción comercial de identidades, el triunfo de la inautenticidad, de la representación inducida o la economía del simbolismo, abren amplias expectativas en el estudio del valor simbólico del paisaje. El acercamiento que experimenta la praxis geográfica al estudio del intangible espacial, vinculado al descubrimiento de las geografías emocionales, además del creciente interés que dispensan las ciencias de la comunicación al discurso territorial, permite, mediante una propuesta de fusión de los saberes geográfico y comunicativo, plantearse abiertamente el estudio comunicativo del paisaje. La cuadratura de las variables geografía, paisaje, emoción y comunicación posibilita el avance hacia el análisis de la emocionalización del espacio para así entrever su valor intangible, que emerge a partir de la aplicación de variadas técnicas de comunicación.

Palabras clave: Paisaje, comunicación, identidad territorial, branding, intangibles.

\footnotetext{
1 Manuscript received April 30, 2010, accepted december 9, 2010 and amended on December 14, 2010.

2 Cátedra de Geografía y Pensamiento Territorial,
}

Universidad de Girona (España). E-mail: joan. nogue@udg.edu

3 Departamento de Comunicación, Universidad de Vic (España). E-mail: jordi.saneugenio@uvic.cat 
Communication research has investigated the concepts of space and environment in some depth, but not the notion of landscape which has been a cornerstone of the geographic academic tradition over the last two centuries, and is also a key element in today's town and country planning policies. Indeed, the European Landscape Convention, adopted in Florence in the year 2000, has greatly contributed to introducing the concept of landscape into the territorial policies of all the ratifying states. Ratification of the convention will involve (and is already involving) an extraordinary quantum leap in the treatment of landscape, not only in territorial and town-planning legislation, but also in the cultural and social debate.

In our contemporary society, landscape is undeniably a geographical concept with one of the highest communicative dimensions. Landscape in almost all its forms and variations is used over and over again in the contemporary communication process; however, there has been no interpretation of this process in terms of the landscape itself, no analysis of its basic components, and no approach to its complex, many-sided dimensions. The present article hope to bridge this gap and it is written as an essay on methodology from the dual perspective of geography and communication. Likewise, communication field can benefit from the rich geographical heritage of reflection on the concept of landscape; conversely, geographers can benefit from the valuable concepts and analytical tools of communication research in order to further our understanding of the communicative dimension of landscape.

The present article gives a brief introduction to the basic issue of landscape, stressing its intrinsic relationship with territorial identification processes, something which is clearly fundamental in the communication context. Next, some contributions from the theory of geography are showed that may be valuable in a communicative approach to landscape. Later, the article mentions a few examples (intangibles in landscape, reality and the representation of reality) and a case study (Landscape Observatory of Catalonia) of wellknown communicative uses of landscape to reach a conclusion that point the need of a research programme that definitively links landscape and communication. Finally, this article shows a relatively new approach to the study of the landscape's communicative dimension: the place brands and landscape branding.

\section{Landscape, territorial identity and representation}

Landscape has never before come under so much discussion, either in specialist fields or in the mass media. This phenomenon is due to various reasons: the progressive environmental awareness over the last twenty years, which has indirectly benefited the landscape; the galloping sprawl of the dispersed city which, for the first time in history, has transformed the appearance of many territories in a short space of time; the establishment of many different types of infrastructures, often regarded as unpleasant and irksome by the inhabitants of the affected areas; a heightened aesthetic sensitivity by certain public opinion-forming groups and associations; and finally, the significant role that landscape has always had in forging and strengthening territorial identities.

On the whole, people feel themselves to be part of a landscape, with which they establish a deep, intertwining complicity. This feeling is ancestral, universal and absolutely legitimate. However, it is a fact that the dialectical tension created by globalisation between "local" and "global" is greatly affecting many places; it is also true that, to a large extent, we still act out our lives within a territorialized culture where landscape plays a prominent social and cultural role. The landscape has always been a main ingredient in people's sense of place, although many places, and their landscapes, are now suffering the impact of telecommunications, faster transport systems, global markets and standardised fashions, products and consumer habits. However, despite all of that, the vast majority of places still preserve their own character, and people have not still lost their sense of place. People are reluctant to lose such sense of place: people are unwilling that someone dispels their landscape's 
idiosyncrasies in an instant. Today's territorial conflicts prove this point.

Landscape still plays a key role not only in creating territorial identities, on every scale, but also in upholding and consolidating these identities. When we talk about landscape, we are talking about a portion of the earth's surface which, over decades or centuries, has been shaped, perceived and interiorised by the societies that live in that environment. Any given landscape is full of places that embody experiences and aspirations of its people; places that have become centres of meaning, or that symbolise thoughts, ideas and emotions. The landscape does not merely present the world to us as it is; it is also, in some way, a construct of this world, a way of seeing it. The landscape is, to a large extent, a social and cultural construct which is anchored, needless to say, in a physical, material substrate. The landscape is both a physical reality and the cultural representation that we make of it; the external, visible physiognomy of a certain portion of the earth's surface and the individual or social perception that it generates; a geographical tangible and its intangible interpretation. The landscape is at once the signifier and the signified, the container and the content, reality and fiction. Most definitions and acceptations of the term "landscape" include the perceptive element or the cultural dimension to which we refer. The above-cited European Landscape Convention defines landscape as "an area, as perceived by people, whose character is the result of the action and interaction of natural and/or human factors". Regardless of our perspective, there is a communicative dimension at the heart of the concept. Landscape cannot be conceived without an individual or collective observer, whose gaze confers identity upon a given territory.

To a large extent, contemporary geography understands landscape in the way that we have just said. Nevertheless, landscape is nowadays once more a major area of research, mainly due to contributions coming from the new social and cultural geography within the Cultural Studies framework. The landscape is understood as a system of signs and symbols, rather than seeing it merely in terms of form. However, in order to fully comprehend a landscape, it must be understood its oral and written representations not just as "illustrations" but as images that constitute its meanings. If culture is conceived as a system of meanings conveyed by a set of mediators and representations, landscape plays an essential role insofar as it contributes to the objectification and naturalisation of culture. The landscape not only reflects the culture, it is part of the culture and, therefore, the active expression of an ideology (Lash and Urry, 1994). landscape has to be understood as a "regard" or way of seeing, we realise that the regard is usually not free. This is why we need to decode the symbols and signs inscribed in the landscape, as well as their function as transmitters of codes of behaviour and relationship.

Over the last few years, the study of landscapes in geography has taken an interesting step forward, beyond mere aesthetic description and beyond its consideration as the result of cultural tradition applied to a territory (Barnes and Duncan, 1992; Mitchell, 1994). There is a need to analyse which landscapes are currently being turned into spectacles by city marketing campaigns that highlight their distinctions or similarities and reinterpret their past. The theatricality of the landscape takes on epic dimensions in certain rural areas, where it is often identified as a symbol of the origins and the purity of national identity, even if the areas in question today have become political and economical backwaters in today's world. In accordance with postmodern logic, our construction and grasp of reality are a constant play of languages, meanings and representations. The world and its multiple places and landscapes can be read as texts: within the framework of deconstruction, intertextuality becomes the new discourse. The discourse is neither stable nor unquestionable, but diffuse and volatile: the challenge consists in seeing how these texts are being read by their multiple readers (inhabitants, visitors or spectators of a city, for example); in analysing how the information is encoded (its signs and messages); and in taking into account the fact that these codes can be interpreted in dissimilar ways, depending on the different power relationships involved (Scott, 2001; Simard, 2000; Nouzeilles, 2002). 
It should be unfair not admit that geography has come this far after fifty years of reflection on the subjective element in the perception of space, and in the perception of landscape in particular. David Lowenthal (1961) paved the way for behavioural geography to explore the field of personal geographies (Downs, 1970). Another major step forward came with the study of the decisive role of human perception in shaping images of our physical environment (which eventually affects the bases of individual and group behaviour) (Frémont, 1976; Bailly, 1977). From 1970 onwards, humanist geography highlight again the role of the subject as the centre of geographical construction, beyond mere perception. We straight forward to the geography of human experience, focused on the values and the concept of place as a centre of meaning and personal identification, as a space of emotional bonding. This phenomenological approach to geography searched for a holistic, subjective, empathetic knowledge of space through immersion (Buttimer and Seamon, 1980; Relph, 1976; Tuan, 1974; Tuan, 1977). Some years later, the debate was enriched by contributions from postmodernism and by a renewed attention to issues concerning language, forms of expression and representation of the world, and the human experience of time and space (Soja, 1989; Nogué, 2008). Finally, there is a renewed interest today in the spatiality of emotion, feeling and affections. The growing awareness of the emotional interactions between people and places is exemplified by the new interdisciplinary academic journal Emotion, Space and Society. Themes hinted at by humanist geography in the 1970s are now taking on new significance: emotional spaces and globalization; rootedness v. uprootedness; emotional architectures and the landscapes of emotion; semiotics and poetry of affection and emotion; public space and emotion; politics and emotion; among many others. This new tendency has been reflected in Emotional Geographies (Davidson, et al. 2005) and Entre paisajes (Nogué, 2009), among others.

However, despite this rich tradition and its close links with the communication world, the communicative dimension of landscape has hardly been approached from the geographical point of view. Moreover, the few existing approaches do not take into account contributions from the communication field. As we will now see, these contributions can be very useful.

\section{The communicative scope of landscape}

The concept of landscape is linked above to that of territorial identity. This interconnectedness is precisely what underlies the growing interest in the communication possibilities of landscape. Nowadays, much interest is focused on the creation of territorial identities linked to the need for a meaningful brand image for marketing and publicity strategies. We shall now examine some major communicative uses of landscape.

\section{Intangibles in landscape}

The path towards a communicative approach to landscape entails, in the first place, seeking out its added values in order to optimise exploitation of the intangible. This tendency involves exploring the implicit message in the landscape and provides an opportunity to probe beyond the physical and/or natural dimensions and to delve into the aesthetic, moral, symbolic and identitarian values of landscape. Despite their apparent intangibility, all are communicable potentially values.

Advertising agencies, marketing consultants and communication research groups are increasingly focusing on researching and implementing new territorial communication techniques in the widest sense (tourism promotion in various formats, city marketing, branding, organisation of territorial-based consumer events, etc.). The aim here is to advantageously position the different geographical areas and to strengthen their commercial value by means of an emotional message linked to a specific territory.

The design of this type of language (similar nature) requires an additional effort in the difficult task of defining research methodologies, in order to define the values associated with a certain place, over and above mere taxonomic classification. It is 
about delimit the methodologies required to enumerate the non-physical (intangible) values linked to a given territory or, as is often the case, to the heritage associated with that territory (Rössler, 2003; Deacon et al., 2004). This reading of the landscape seeks to understand its intangible values, in terms of its associated symbols, aesthetics, identities and mythologies. Different techniques are brought to bear on the arduous task of recording the intangible values of a physical space, as well as the city and tourism brand images designed for identitarian, tourism and territorial positioning. It should be remembered, at this point, that the marketing of spaces has existed for a long time, e.g. in the area of tourism promotion. However, the recent need to position certain geographical places by creating brand images linked to territorial identities has brought about a huge increase in communication strategies based on spatial inputs, largely arising from the exploitation of the huge communication potential of landscape.

Indeed, landscape plays a major role in the process of shaping, consolidating and maintaining territorial identities (Nogué, 2007). In that sense, it has become a central communicative theme in city marketing and tourism promotion strategies. There is a surprising interest nowadays in defining imaginaries and in constructing territorial identities, all of which are in paradoxical dissonance with the contemporary homogenization of spaces and places. We are witnessing a demand for territorial "denomination of origin" based on claims for historical, cultural, religious and ethnic roots. On a global scale, an increase in the identity variable within our so-called information society: a revalorization of places; a growing need to be unique; an urge to highlight the significant features that set one place off from all the others is confirmed. The landscape is precisely one of those features (Nogué, 2007 and 2008). However, an interesting antagonism repeatedly crops up between reality and representation which is seen today, perhaps, more clearly than ever before.

\section{Reality and the representation of reality}

It seems true that contemplation of real contemporary landscape is often tinged with our idea of an archetypical landscape (Roger, 1997) which has been passed down to us from generation to generation through numerous ways: landscape painting, photography, the media, the education system, and so on. The lack of legibility and the loss of imaginaries in many contemporary landscapes have a strong link with what it could be describe as the "crisis of representation". This refers to the growing gap between the archetypical landscape passed down from generation to generation and the real landscape which is becoming increasingly homogenous and inconsequential, in particular in tourist areas and on the outskirts of towns and cities. The idea of an archetypical landscape came into existence within the context of "socialization" of landscape by cultural, literary and artistic elite who, at a certain point in history, created and disseminated the metaphor of landscape. It remains to be seen, of course, whether the selected image was a majority choice, and which of other images were rejected. We must also accept that, as social representations of landscape, any such other images are, or were originally at any rate, equally legitimate in social terms. Be that as it may, a socialization of archetypical landscape occurred in the past, reaching us today through various images which have fused over time into a collective, shared and socially accepted imaginary. An example of this is the powerful English landscape archetype, in which the past still plays a large role. The English are well known for their skill of seeing the landscape through its associations with the past and for their tradition of appreciating places in terms of their historical connections. For the majority of English people, a neat, green, bucolic countryside with picturesque deciduous woods constitutes the ideal of landscape beauty. The landscape is valued almost as an antique treasure. David Matless (1998) goes even further in Landscape and Englishness when he shows how a typically English landscape constitutes one of the basic components of "Englishness" or of "being English". In France, Yves Luginbhul (1989), Augustin Berque (1990 and 1995), Alain Roger (1997) and especially Pierre Nora (1984) in their jointly-written Les lieux de mémoire, each develop the same idea in their own way. 
In Catalonia (Nogué and Vicente, 2004), scholars of the Catalan modernista and noucentista movements have reached the same ascertainment. The basis of contemporary Catalanist thought was laid down in the period between the late 19th century and the first third of the 20th century. These basis are characterized by containing two contradictory roots of modernisme and noucentisme, and this also applies to the history of landscape. The former movement responds to the canons of Germanic-inspired romantic nationalism; the latter movement developed out of a classical nationalism replete with references to Mediterranean culture, civic in appearance and based on action. Both perspectives have had farreaching influences as far as concerns the territory and the landscape. Modernista and noucentista thought generated the dual landscape archetypes which flourished throughout $20^{\text {th }}$-century Catalonia. On the one hand, there is the archetype of the green, humid, mountainous Catalonia of the Pyrenees, which originated in the $19^{\text {th }}$. century Renaixença Catalan cultural revival and was later taken up by modernisme; on the other hand, we find the noucentista archetype of the sunlit, maritime, intensely humanised Catalonia of the Mediterranean. The two archetypes have co-existed over time, alternatively complementing and excluding one another. Which has been the predominant archetype? Which of the two landscape discourses has been the favourite? The answer, of course, is modernisme, still the hegemonic discourse in Catalonia today. In point of fact, the recovery of Catalan democratic institutions from 1978 onwards meant not so much a renovation of the identitarian discourse in terms of territory and landscape, as a return to the bases generated seven decades previously. In more concrete terms, this meant the enhancement of the archetypical mountainous landscape and, by extension, of traditional Catalonia. In terms of architectural heritage, this meant an absolute predilection for Romanesque and Gothic art and a near disdain for Baroque and Neoclassicism.

The landscapes of reference lodged in the collective unconscious come into head-on collision with the real landscapes that are seen every day by most European citizens, which makes, as we have already said, to a crisis of representation. The semiotic reading of contemporary landscapes subjected to intense transformations is a complex undertaking. The decoding of the symbols in these landscapes is not an easy task. The legibility of new metropolitan landscapes is even more complicated than that of the compact urban landscape described in urban semiology. In his classic treatise on the image of the city, Kevin Lynch (1960) highlighted five essential categories for reading a conventional urban landscape: paths, edges, districts, nodes and landmarks. Which categories, which ciphers enable us to interpret the modern sprawlscape? The categories and ciphers undoubtedly exist, probably intended more for drivers than for walkers, but they are almost certainly more ephemeral and more difficult to read than the five categories enumerated by Kevin Lynch. It is not easy to fit in the fractured and blurred landscapes on the city outskirts into a clear, logical discourse. These areas may seem itinerant or nomadic; they are repetitive and the same all over. Territories seem to have no discourse and the landscapes seem to have no imaginary. Their legibility has become so extremely complex that it comes close to invisibility.

\section{Landscape, advertising and the city}

The landscape field offers huge opportunities for advertising. Advertising language is guided by the principles of persuasion, and media make extensive use of landscape to transmit advertising messages. Advertising professionals use the "support" of landscape not merely as a physical background for a commercial; but they also exploit its implicit capacity of evocative communication to develop emotional themes that are used to influence potential receivers of their message. The use of landscape in advertising is now becoming notorious, in particular the ones that promote the sale of cars and tourist destinations but also for selling many other types of goods and services. Thus, the creation of an image which locate cities on the territorial commercialisation market usually falls back on the "evocation of landscape" technique, in its attempt to project the city through its landscape, in symbolical, cultural and 
identitarian terms. The final audiovisual projection in the media usually materialize in the form of a coastal, urban, rural or mountainous landscape.

The representation of a landscape is able to take up and to evoke at the same time the full symbolic and identitarian burden of an advertising campaign designed to promote a territory. In this case, it is an audiovisual precision exercise and an optimisation of the communication opportunities that afford the landscape to sell a given space. Advertising professionals use the landscape as a semiotic icon (Gottdiener and Lagopoulos, 1986), with all its emotional and intangible inputs, as the raw material for exploiting the symbolic and identitarian aspects existing in a territory. The future challenges of the western world cities willrevolve around their placing on the market with an exaltation of their intangible values (sustainability, tolerance, talent, innovation, intercultural level, quality of life), all of which are usually conveyed by a brand image enhancing the urban landscape.

In short, landscape is becoming a key factor for advertising both territories and cities; not only of tourism promotion campaigns but also, and above all, of territorial identity creation, where we are wont to find a communicative reiteration (or redundancy) between reality and its representation, i.e. between the original and the copy. We are talking, in short, about the staged authenticity, a paradigmatic expression used by MacCannell (1999) to name a theatrical representation of the reality. One curious example is the recent proliferation, in the main access roads to towns and cities, of enormous billboards showing nothing other than an image of the place we are approaching (Nogué, 2009). It consists of a huge photograph of the most typical and, stereotyped image of the town or city in question. What is interesting about this, however, is that the billboards are often placed in such a way that people perceive the real landscape and the represented landscape (the original and the copy) with a glance. People do not always know which to look at first, or how to look at it, given that both the real and represented images are apparently the same.
What it is here is a trivial and superficial version of something much deeper, the thorny problem of the complex relationship between reality and its representation which has been basic in art history. The issue has been considered and reformulated to such an extent that art history is largely the history of the reality-representation binomial. Artists themselves have explicitly and ingeniously expressed the conundrum from time to time, as for example Velazquez with Las Meninas or Salvador Dali with Dali from the Back Painting Gala from the Back. Realist movements approached the reality-representation relationship from a global perspective, whereas the avant-garde approach has been more fragmented, and focused on colour (impressionists), on shape (cubists) or on movement (futurists), to give but a few examples. Contemporary art has regained the global and holistic perspective of the reality-representation issue, which had been partly lost over the last century and a half. Conceptual art has also often addressed the subject. Peter Campus' ground-breaking work Interface (1972) shows a reflection of the viewer on a screen and a live video of the same viewer projected onto the same screen. The two images are brought together into one single vision.

The above-mentioned billboards are a watered-down version of the idea espoused by conceptual art of forty years ago, but it is devoid of creative, experimental intent or of critical reflection on the ever-blurred borders between reality and fiction. We are currently immersed in a society of induced visualisation, in which construction of images has surprisingly triumphed over landscapes. Images of landscape are so extremely commonplace in our visual universe that they impinge on our perception of reality. In an aesthetic appreciation of landscape, what is known (visual information on the landscape) determines and questions what is experienced (real experience of the landscape). A landscape is often described as beautiful when it is recognised in it something which has been previously endorsed by the media. In fact, the success or failure of the tourism or travel experience depends largely on the extent to which the landscapes that we see "live" correspond to the images in the magazine, documentary or 
travel agency which inspired us to go there in the first place.

This is a classic case of the commodification of places and their landscapes, which is so much part of postmodern societies and economies. One of the basic paradoxes of postmodernity, within the context of the crisis of authenticity, is the clear differentiation between reality and its representation on the one hand and on the other the corresponding celebration of themepark style inauthenticity. It seems clear that we are moving towards a thematisation of landscape: the above-mentioned billboards are probably best understood when they are considered from this perspective. We are being shown what we could quite easily see for ourselves. This is not an exercise in cheap city marketing; as we have said, the real landscape must be media-tised in order to gain relevance; it must go through the powerful filter of the image (preferably a stereotyped image or, better still, an archetypical image). Consumption of a place is not complete without previous visual consumption of the images of that place, as described in John Urry's exploration of the "tourist regard" in his perceptive treatise on the semiotics of the visual image. Kenneth Gergen in The Saturated Self (1992) also raises issues that are relevant to landscape. He wonders whether normal relationships can match the power of the media in a world where holidays cease to be real if there are not filmed; where weddings are turning into photo and video events; and where sports fans follow matches on television because the game seems more real on the screen than in the stadium. Gergen observes that people are turning increasingly to the media, rather than to their sensorial perception, in order to be told what is happening.

\section{A case study: landscape and communication at the Landscape Observatory of Catalonia}

\section{The Landscape Observatory of Catalonia}

The Landscape Observatory was conceived as an advisory body of the Government of Catalonia and society in general in landscape matters and as the centre par excellence for the study and follow-up to the evolution of landscapes in Catalonia and the agents which condition its dynamism. The basic and generic objective of the Landscape Observatory is the study, identification, follow-up and documentation of Catalan landscapes and their transformations, without this meaning any neglect of reflecting on landscape in a generic way.

One of the principal objectives of the Landscape Observatory is to increase the knowledge that Catalan society has of its landscapes, to collaborate with the Government of Catalonia in implementing landscape policies and, in general, to support the application of the European Landscape Convention in Catalonia. In that sense, it is seen as a meeting point between the authorities (at all levels), the universities, professional groups and the whole of society in relation with everything concerned with landscape. Its creation answers the need to study the landscape, prepare proposals and make Catalan society aware of the need for greater protection, management and planning of the landscape in the framework of sustainable development. The Landscape Observatory is, therefore, a sort of a great umbrella under which anyone interested in landscape can take shelter.

\section{Functions and objectives of the Landscape Observatory}

Its functions, which are set out in its Constitution, are the following: Establishing criteria for the adoption of measures of protection, management and planning of the landscape; fixing criteria to establish the landscape quality objectives and the necessary measures and actions destined to achieving these objectives; establishing mechanisms of observation of the evolution and transformation of the landscape; proposing actions directed to the improvement, restoration or creation of landscape; preparing the Landscape Catalogues of Catalonia, to identify, classify and qualify the various existing landscapes; promoting campaigns of social sensitisation with respect to landscape, its evolution, 
functions and transformation; dissemination of studies and reports and establishing working methodologies in landscape matters; stimulating scientific and academic collaboration in landscape matters, and exchanges of work and experiences between specialists and experts from universities and other academic and cultural institutions; a follow-up of European initiatives in landscape matters; organising seminars, courses, exhibitions and conferences, as well as publications and specific programmes of information and training on landscape policies; creating a documentation centre open to all the general public of Catalonia. The Observatory has another function established by the Landscape Act: every four years it must prepare a report on the state of the landscape in Catalonia which is presented by the Catalan Government in front of the Catalan Parliament.

\section{Designing landscape indicators for Catalonia}

The landscape indicators are key factors in following up the state of the landscape in Catalonia and in the application of landscape policies at all levels. The Landscape Observatory defines and applies a list of landscape indicators, based on environmental, cultural and social viewpoints, which will enable the state of the Catalan landscapes and their evolution to be measured, as well as landscape policies in Catalonia, following the principles of sustainable development. The indicators will be useful in the preparation of the landscape catalogues and, naturally, in preparing the four-yearly report on the state of landscape in Catalonia referred to in the Landscape Act.

The provisional list of indicators we are working with is the following: transformation of landscape; landscape diversity; landscape fragmentation; economic value of the landscape; knowledge of the landscape; landscape sociability; landscape and communication; landscape satisfaction; application of the instruments of the Act for the Protection, Management and Planning of the Landscape in Catalonia; public and private action in the field of conservation.

\section{The communicative strategy of Catalonian landscape}

\section{a) Landscape Observatory Web}

To facilitate dissemination, training and sensitisation in relation to landscape, the Observatory has created a web ${ }^{4}$ available in four languages (Catalan, Spanish, English and French). This site, created with the intention of being a source of reference for anyone interested in landscape, supplies information on the Observatory's activities, landscape policies, conferences and activities related with landscape, and information on Catalan, Spanish, European and international institutions which deal with landscape from different perspectives, reference publications and university studies linked with this theme.

\section{b) Publications of books}

The Landscape Observatory of Catalonia has two collections of books under the name of "Plecs de Paisatge" and "Documents". The collection "Plecs de Paisatge" has two series: 'Reflections' and 'Tools'. The first includes articles, studies, workshops and conferences which consider, either generally or through specific cases, a particular aspect or problem related to the landscape. On the other hand, the series 'Tools includes regulations, instruments and methods for the protection, management and planning of landscape. As the name states, "Documents" is a collection of small documents on landscape that, because of their size and subject, fail to adapt to the "Plecs de Paisatge" collection. Since June 2009, the Observatory has already published the books: Landscape and Health and Landscape Indicadors. Challenges and Perspectives. And the following books are about to publish: Instruments de gestió $i$ ordenació del paisatge a Catalunya i a Europa (Instruments of Landscape Management and Planning in Catalonia and Europe), Els Paisatges sonors a Catalunya (Sound Landscapes in Catalonia) and La participació ciutadana en els catàlegs de paisatge (Public Participation in the Landscape Catalogues).

\footnotetext{
4 Can be visited at www.catpaisatge.net
} 
c) Dissemination of information on landscape in three electronic newsletters

The Observatory has three electronic newsletters. First was the Dietari de Paisatge (Landscape Diary), a weekly newsletter which since May 2005 contains news on landscape published in the principal communication media of the world, addressed to people specialised in landscape and with responsibilities in management. The second, Paisatg-e (Landscap-e), set up in September 2006, is of broader dissemination and includes expert opinions on landscape at international level, news related with the Observatory, important novelties on landscape around the world, regulations, articles of interest appearing in the press, a schedule of activities, seminars and conferences. The third one, Landscape Events, set up in October 2007, offers the user monthly a selection of congresses, seminars, courses, presentations, conferences and exhibitions, among other events around the world, with a special emphasis on those taking place in Catalonia.

\section{d) Activities in training and social sensitisation}

One of the principal objectives of the Landscape Observatory is the promotion of training and social sensitisation campaigns in relation to landscape. In that sense the Observatory has worked in coordination with and on the initiative of the Government of Catalonia in the preparation of teaching material for use in secondary schools under the title "City, Territory and Landscape". The idea is that pupils in the second stage of secondary education, through this innovative material, will understand not only the diversity of Catalan landscapes, but also will be aware of its associated risks and threats. As well as printed classroom material, the Landscape Observatory created a web page for the project, which broadens and goes more deeply into the content of the twelve prints referred to and encourages the use of the new information technology in learning processes.

\section{The communication of landscape through place brands}

\section{Place branding: history and meanings}

Place branding starts from the conviction that points out that place brand can be done in the same way that the product, services and corporations brands are done (Moilanen and Rainisto, 2009). Although Anholt (2005a) insists on the need of to not confuse the branding term for the promotion of the individual assets of a nation, as tourism, inward investment, culture or exportations. The same Anholt (2007) defines branding as design, planning and communication process of a name and identity, in relation with the creation and/or management of a reputation. It has nothing to do for example with the isolated deployment of a logotype or a slogan (visual identity). This point should be quite clear, as the literature that is related to place branding insists on the need to let clearly understood that branding is a transverse process of management and communication of a territory and in any case implicate, only, a precise promotional action (Dinnie, 2011).

In that sense, Anholt (2005b) draws a distinction between different definitions of branding practice. A first definition refers to a popular and quite unclear concept and sometimes related to $360^{\circ}$ communication, marketing and public relations. In this context, branding is identified as a passing fad associated to modern sale techniques, therefore, accumulates bad connotation.

According to Anholt (2005d), the second definition is related to a simple conception of the process and it usually refers to a certain visual identity (name, logotype, slogan). The last definition of the notion has connection to an advanced conception of brand and branding, which includes more simple definitions, but, at the same time, highlights in its interface function between personality, product and/ or service of a company -in our case places- and its potential consumers. In that type of advanced vision of branding, what adopts special importance is not functional and/or physical attributes, but 
the specific job with intangibles. In that way, as Anholt points out, brand becomes a key mechanism in the running of any organization, and is consolidated as its most valuable asset. This last approach, the most advanced, is the one that takes places during the transfer of corporative branding to place branding (Anholt, 2005d, Govers and Go, 2009).

Likewise, Anholt (2005c, 2010) points out that the advanced notion of brand loses part of its mercantilist connotations, because is addressed to people and not to markets. It is in that sense, that this author prefers to use the expression competitive identity to the detriment of place branding, which he defines as (2007:3): "Competitive Identity (or Cl) is the term I use to describe the synthesis of brand management with public diplomacy and with trade, investment, tourism and export promotion. $\mathrm{Cl}$ is a new model for enhanced national competitiveness in a global world, and one that is already beginning to pay dividends for a number of countries, cities and regions, both rich and poor."

The most surprising thing about the competitive identity notion is that Anholt (2007) understands this process in a not induced and previous planned way, but in a organic and/or spontaneous way, with the previous conviction that the reputation of a country or nation must depend on lots of factors (this author uses an hexagon to explain his concept of competitive identity in which variables as tourism, brands, people, politics, culture and investment are included). Therefore, he considers that in some way must be necessarily the end of a path and not the beginning of it, in the sense of state that a good place management in the areas that his explicative hexagon points out and will automatically involve a good reputation for a country, region, city, etc. (Huertas, 2010).

Anholt also uses the terminology change to put an end to the inherent semantic confusion to branding and its inevitable commercial connotations, and suggests a new concept that it is separated of the traditional marketing and corporate sphere. Likewise, Anholt makes a interesting transposition of the commercial branding components in place field: a) Identification of the brand: it is related to the national identity, although all the related communication branding techniques with its visual identity (logotype, slogan, packing, etc.) and its graphic design are little relevant in the countries field, on account of its high complexity.

b) Brand image: it becomes the brand perception present in the user mind. Anholt compares this with the place reputation, which becomes essential in the performance and final election of the consumers. Brand image is a critical concept when there is talk about nations, cities or regions.

c) Brand purpose: compared to comparative culture. According to Anholt (2007), it is considered the internal equivalent of the brand image. It represents "the spirit of the organization", "the experience of the brand", the shared internal values.

d) Brand value: lies in a positive, powerful and solid reputation, which on the rebound creates income for certain territories.

Kavaratzis and Ashworth (2005, 2010) add the aspect related with the brand placing as a part of the proposal of value informed to a certain public that shows a competitive advantage. Kavaratzis (2005) points out that there exist nowadays three models of place branding with meanings quite different:

a) Geographical nomenclature: when a physic product takes the name of a geographical location without a link between them, for example champagne (France region). On this point, we should refer to geobrands or geographical brands that are defined in denomination and/or distinctions which join the commercial field and come from explicit mentions of the territory. In Spain coexists the guarantee of origin and quality of a wine $\left(\mathrm{DOQ}^{5}\right)$ and the protected geographical indication $\left(\mathrm{IGP}^{6}\right)$. According to LópezLita and Benlloch (2006), there are some typologies of associated brand

5 Abbreviation for Denominació d'origen i qualitat.

6 Abbreviation for Indicacions geogràfiques protegides. 
in the inherent environment of the place. For that reason, the geographic spaces that keep their common features (Mediterranean region, Cantabria region, etc) or singularity of the places associated with cultural, socials and gastronomically criteria (the Rioja route wine, among others) can be considered, in the same way, place brands.

b) Products and places cobranding: when a physic product is associated with a place that transmit beneficial attributes to the product image. A few examples are Swiss watches, German cars, Japanese televisions o Finish mobile phones. In the particular case of commercial brands, the company DAMM, brewing industry, with headquarters in Catalonia includes the toponym Barcelona in the labels when exports the production of beers abroad. The same thing happens with fashion designer Custo Dalmau and his commercial brand Custo Barcelona, in which the combination of brand values (design, innovation, modernity, creativity, cosmopolitanism, etc) and the values of the Catalan capital converge and feed on each other. In that sense, a survey taken in 2010 by the Barcelona Centre de Disseny observatory (BCD) points out that the incorporation of the Barcelona term to a company and product brand is synonymous with fame and exports increase, according to those forty companies polled. Therefore, apart from identify the origin of the company, the inclusion of the Barcelona toponym by some corporations create a positive automatic annexation to the values and iconography of the city.

c) Branding understood as a place management: essentially, place branding is a way of place management, as the places management depends on the perception that individuals have of a certain space. Therefore, it is about generate a place identity to produce changes in the image and reputation of certain geographic spaces and, on the rebound, modify the performance of potential customers.

\section{Emotion, brands and space. Emotional geographies}

The study of emotions has traditionally been linked to esoteric matters (Anderson and Smith, 2001), verging even on metaphysics, in what amounts to an unfair treatment of an area of knowledge considered vital for approaching a geography of sentiments, of emotions, of attachment. Indeed, research work on aspects linked to emotion has generally silenced, despite representing an excellent thread for the understanding of human life experiences.

Emotion has remained within a private sphere, away from public life and even further from being an object of enquiry for academic research. Anderson and Smith (2001) believe that the reason of this lies in the gender-based differences existing in knowledge production. Rationality and objectivity have been historically associated with masculinity, whereas subjectivity, passion and desire were commonly devalued as values associated with femininity. The specific contribution of geography towards a reassessment of the role of emotion in the various fields of applied research finds interesting perspectives within the concept of "emotional spaces". Acknowledgment of the importance of emotion in the contemporary context, and in particular of its contribution to geographical knowledge, is the first step to legitimising emotion as a valid path towards knowledge. However, Anderson and Smith (2001) point out that, despite the obvious power of emotional relationships, only rigorous work methodologies will bring about major changes in the academic treatment of emotion.

The contemporary city, postmodernity and the economy of symbolism have all generated new variables linked to personal and group experience, as well as to empathy, affection and emotion. Thien (2005) points to a certain explosion of inter-subjectivity that is taking place in the beginning of the 21 st century, which is linked to the growing importance of social, cultural and gender geographies. In Thien's opinion (2005), this may spring from a renewed interest for the body as a discourse, the growing consumption of culture and, 
in short, the gradual commercialisation of emotions.

Emotional geographies can extend their sphere of influence to include aspects related to geography, gender studies, cultural studies, sociology and anthropology, and any other discipline that helps to understand how the world is influenced by sentiments (Thien, 2005: 451).

In this context, symbolic geographies (or the "geography of emotion") are coming to the fore as a field of geography, insofar as they represent the search for affective links between societies and their spaces, or for experience coming from interaction with place (Davidson, Bondi and Smith, 2005), jointly with the growing interest from the advertising world for specific communications work with territory, we can glimpse the connections emerging between the new geography of emotion and the proliferation of persuasive emotional communication strategies linked to territory (place branding, destination branding and landscape branding).

\section{The emotional experience of landscape. Landscape branding}

A common practice used by advertising agencies is to set up communication processes in order to position a territory advantageously in comparable or competitive terms. At first sight, this means that the advertising standards are transferred to the competitive management of space in order to create an optimal brand image which, in our case, means the best territorial brand image. This is usually carried out by enhancing the intangible attributes of a certain territory, space, landscape etc.

Advertising is traditionally associated with encouraging the consumption of certain products, goods or services, with clear commercial aims. In the case of spatial advertising, it has evolved into the relatively recent phenomenon of brands and branding. According to Kotler, (2000: 404) "a brand is defined as a name, term, sign, symbol, design, or a combination of them, intended to identify the goods or services of one seller or group of sellers and to differentiate them from those of competitors". Brands tangibilize certain personal options or ways of life and, in this manner, depart from purely commercial functions. Brands as such can turn into hallmarks of personal, group or even territorial identity and are among the most significant contributions to popular culture ever made by commerce (Olins, 2004: 17).

The concept of brand is linked to that of brand identity, defined by Aaker (1996: 24) as "the set of assets and liabilities linked to a brand, its name and symbol that add to (or subtract from) the value provided for a product or service to a firm or to that firm's customers". According to Marca (2008: 155), branding refers to the creation of brand value, by strategically administrating all the assets and liabilities directly or indirectly linked to the name or symbol (Isotype) identifying the brand and thereby influencing the value provided. There has been some attempts to dissociate branding from advertising, in its strictly commercial sense. However, as will soon be seen, territorial branding also provides a privileged showcase for viewing the latest trends in territorial brand image creation in which space, communication and emotion are variously combined.

The highest expression of the "emotionalisation" of space is found when branding is applied to the spatial discourse. It seeks here to construct territorial identities of places (place branding) and destinations (destination branding), and to develop its own identitarian, emotional discourse out of the symbology, values and intangibles of landscape (landscape branding). In that sense, Gunn (1972) differentiates two main components in the social construction of certain images. On the one hand, the organic image resulting from first-hand individual experience or objectively-sourced information (films, newspaper articles etc.); on the other hand, the induced images resulting from the external sources created by advertising and by its evolved model of branding.

Landscape branding basically consists of evoking the intangible message implicit in any given landscape, by means of the persuasive, emotional language of communication. Its methods are clearly 
designed to exploit the communicative power of landscape, by channelling the specific values of identity, personality and distinction into the construction of a territorial brand image. The landscape is an excellent communication tool, as well as a valuable showcase of tendencies. The tangible morphology and the intangible value of a landscape are particularly useful for distilling the essential cultural heritage of a given place.

Branding appeals to the induced evocative power of the landscape, in order to transform its message for symbolic and real-life consumption. There is a growing need for analysing how the represented discourse (prefabricated discourse or induced discourse) of the landscape bestows certain values upon a given space. In this respect, a wide range of interdisciplinary research openings are opening up in the specific field of spatial brand image creation.

In the last analysis, landscape branding represents the current trend towards the communicative management of the implicit emotion in landscape. It is a communicative intelligibility exercise of the intangible values present in the landscape. Landscape branding is a commercialisation of the geography of symbolism, with specific use of the variables of affection, emotion and sentiment. It is an instrumentalization of the symbolic, identitarian value of landscapes leading to what Nye (2006) calls the "soft power" of the culture industry within the convulsive context of postmodernism. Nye defines soft power as the ability to alter the behaviour of others by using attraction techniques, rather than by coercion or obligation, in order to achieve the needs of the individual or the group. Soft power develops out of the attractiveness of a country's culture or political ideals and policies, and is far from the historical "hard power" associated with military practices and the imposition of resolve. On a global scale, it represents the triumph of persuasion, suggestion, the power of attraction of the territory and in particular of the landscape. It constitutes a new mental inventory of landscape or, perhaps, an exploitation of the soft power of geographical representation, with everything that this may imply (Van Ham, 2008). In this way, places and landscapes are treated by standards applied to corporative brands (branding) and not by those of mere products (advertising).

The task of creating a brand value for a landscape is, per se, an undertaking of symbolic and emotional intelligibility. The creative processes of "clothing" a given landscape and, by extension, the marketing of a given space had their origins in tourism promotion, but have now evolved into more modern forms related to the language of advertising, such as destination branding and place branding. The state-of-the-art approach to the landscape-communication duality involves the induced landscape, the seduction of the brand name and the triumph of representation (or premeditated symbolic interpretation). Branding appears to be coming into its own as a communication strategy that tangibilises the symbolic value of the landscape, and channels its discourse into demands for the emotional experiences that society seemingly requires with its most personal spaces. For all the above reasons, landscape branding draws together the three basic aspects discussed throughout this article: communication, landscape and emotion. In the past, society evolved more or less naturally towards the concept of "place" by interacting repeatedly with its spaces; nowadays the same thing is achieved in an induced (even artificial) fashion by commercializing the spaces and places, just like any other product or service. Branding (or more precisely place branding and destination branding) is a form of communication with the commercial aim of forging an emotional link between society and certain spaces. In short, branding represents the triumph of small-scale representation of reality, the triumph of artificiality and inauthenticity.

To sum up, landscape branding represents an evolved version of place branding. It involves a specific association of the values and emotions inferred from a landscape, and can also be defined as the commercial expression of "the emotion of landscape". In that sense, a territorial (or landscape) brand identity creation finds exceptional raw material for the identitarian positioning of spaces in the intangible emotion implicit 
in the landscape. The recently invented territorial brands compete to attract the attention in the saturated advertising market, in a climate of keen competitiveness among the (supposedly) postmodern, cosmopolitan cities and the tourist destinations. By explicitly distancing itself from commerce, branding finds its raison d'être in the management of symbolic geographies; the perfect excuse for bringing about this notorious phenomenon in the cities of Europe and the rest of the world. Territories are now being managed and ordered in accordance with brand image criteria, and cities are now being planned to achieve a desired visual morphology. This will end up conditioning the future development of territories, thereby bringing about a drastic change in city management, in which the image conditions all other planning and management policies.

\section{Final considerations}

In the context of globalization, cosmopolitism and fleeting circulation of information, the rapprochement of people to places and spaces seem to happen within a sphere that is neither strictly physical nor ascertainable. In our opinion, we are dealing here with an ethereal, intangible interaction, only explicable within the current climate of symbolism, subjectivism and the exaltation of intangibility as a valid praxis for understanding the relationships between humanity and its spaces. The exaltation of the symbology inherent in territorial logic provides us with a set of dual relationships (geography and symbolism, space and intangibility, landscape and emotion, communication and place) inviting academic exploration into a potential communicative theory of landscape, authorised and legitimised by a careful revision of geographical and communication theories.

Postmodernism, subject geographies (especially perception and humanism in geography) and the perspective of communication provide a fusion of knowledge that paves the way towards an approach to landscape and a model of analysis with which to formulate a landscape's communicative approach. Furthermore, on the one hand our observation of today's communications management of geographical spaces, on the other hand the unremitting tendency towards symbolism, emotion and identities created from territorial intangible reveals that the link between geography (traditionally concerned with places and spaces) and communication (fittingly concerned with the intangible discourse implicit in landscape) can be fruitful on the complexities of noninventorial elements of territory.

The territory plays an increasing role as mediator of communications processes, and in the creation and consolidation of local identities on every scale. This is where landscape obtains an important role, both as a cultural showcase and as a scenario of different interpretations. If it is accepted that the space contains the message, and that the message is transmitted by the symbolladen territory, people must also accept that the landscape plays the leading role in the process. A multi-disciplinary approach to understanding and interpreting the implicit message in the landscape, including some amount of feedback coming from the inhabitants, has clear implications at a communications level. In that sense, a suitable avenue of research must be opened up in response to the demand for studies on communication and landscape, in a period that landscape is a key factor in new territorial planning policies and in the many social and cultural debates surrounding the implementation of the European Landscape Convention.

The need to decode the meanings attributed to landscape, the society-landscape interaction and the recent use of landscape as a "territorial showcase" in the advertising and city marketing field, encourage reflection on the suggestive power of landscape, complete with all its emotional, symbolic and communicational overtones. In this sense, the subject geographies (geography of perception, humanist geography, postmodern geography, emotional geographies) have likewise many points of intersection with the theoretical suppositions of the communication perspective. Coinciding 
tendencies in communication and geography, in particular those related to the interpretation of symbolisms and life experiences, open up new research perspectives into the relationship between landscape and communication.

\section{References}

AAKER, D. A. Building Strong Brands. New York: Free Press, 1996.

ANDERSON, K. \& SMITH, S. Emotional geographies. Transactions of the Institute of British Geographers, 2001, № 27, p. 7-10.

ANHOLT, S. Brand new justice: how branding places and products can help the developingworld. Amsterdam: Elsevier, 2005 a.

ANHOLT, S. Editorial. Place Branding and Public Diplomacy, 2005b, vol. 1, No 4, p. 333-346.

ANHOLT, S. Nation brand as context and reputation. Place Branding and Public Diplomacy, 2005c, vol. 1, № 3, p. 224-228.

ANHOLT, S. Some important distinctions in place branding. Place Branding and Public Diplomacy, 2005d, vol. 1, № 2, p. 116-121.

ANHOLT, S. Competitive identity: the new brand management for nations, cities and regions. Basingstoke: Palgrave Macmillan, 2007.

ANHOLT, S. Places. Identity, image and reputation. United Kingdom: Palgrave Macmillan, 2010.

BAILLY, A. La perception de l'espace urbain: les concepts, les méthodes d'étude, leur utilisation dans la recherche géographique. Paris: CRU, 1977.

BARNES, T. J. \& DUNCAN, J. S. Writing worlds: discourse, text \& metaphor in the representation of landscape. London: Routledge, 1992.

BERQUE, A. Médiance. De milieux en paysages. Montpellier: Reclus, 1990.
BERQUE, A. Les raisons du paysage. Paris: Hazan, 1995.

BUTTIMER, A. \& SEAMON, D. (eds.) The Human Experience of Space and Place. London: Croom Helm, 1980.

DAVIDSON, J.; BONDI, L. \& SMITH, M. Emotional Geographies. Aldershot: Ashgate, 2005.

DEACON, H. et al. The subtle power of intangible heritage: legal and financial instruments for safeguarding intangible heritage. Cape Town: Human Sciences Research Council, 2004. Disponible en Internet: http://www.hsrcpress.ac.za/product. php? productid $=2044 \&$ freedownload $=1$

DINNIE, K. City branding: theory and cases. United Kingdom: Palgrave Macmillan, 2011.

DOWNS, R. M. Geographic space perception: Part approaches and future prospects. Progress in Geography, 1970, № 2, p. 66-108.

FRÉMONT, A. La région, espace vécu. Paris: PUF, 1976.

GERGEN, K. The saturated self: dilemmas of identity in contemporary life. New York: Basic Books, 1992.

GOTTDIENER, M. \& LAGOPOULOS, A. The City and the sign: an introduction to urban semiotics. New York: Columbia University Press, 1986.

GOVERS, R. \& GO, F. Place branding. Glocal, virtual and physical identities, constructed, imagined and experienced. Hampshire: Palgrave Macmillan, 2009.

GUNN, C. Vacationscape. Designing visitor regions. Washington: Taylor and Francis/University of Texas, 1972.

HUERTAS, A. Las claves del Citybranding. A Institut de la Comunicació, 2010, Portal de la Comunicación. Bellaterra: Universitat Autònoma de Barcelona, 2010. Disponible en Internet: http://www.portalcomunicacion. com/esp/pdf/aab_lec/57.pdf 
KAVARATZIS, M. Place branding: a review of trends and conceptual models. The Marketing Review, 2005, vol. 5, No 4, p. 329-342.

KAVARATZIS, M. \& ASHWORTH, G. J. City branding: An effective assertion of identity or a transitory marketing trick? Tijdschrift voor economische en sociale geografie, 2005, vol. 96, № 5, p. 506-514.

KAVARATZIS, M. \& ASHWORTH, G. J. Place branding: where do we stand? In: KAVARATZIS, M. \& ASHWORTH, G. J. (eds.) Towards effective place brand management. Cheltenham: Edward Elgar, 2010, p. 1-16.

KOTLER, P. Marketing management: the millennium edition. New Jersey: Englewood Cliffs Prentice-Hall, 2000.

LASH, S. \& URRY, J. Economies of Signs and Space. London: TCS/Sage, 1994.

LÓPEZ-LITA, R. y BENLLOCH, M. T. ¿Necesitamos marcas territorio? Técnica económica, 2006, № 175, p. 50-52.

LOWENTHAL, D. Geography, experience and imagination: towards a geographical epistemology. Annals of the Association of American Geographers, 1961, № 51, p. 241-260.

LUGINBHUL, Y. Paysages. Textes et représentations du paysage du siècle des Lumières à nos jours. Paris: La Manufacture, 1989.

LYNCH, K. The Image of the city. Cambridge: MIT Press, 1960.

MACCANNELL, D. The tourist: a new theory of the leisure class. Berkeley: University of California Press, 1999.

MARCA, G. Marcas y patrimonio cultural: tangibilización de la comunicación. En: MATEOS, S. (ed.) La comunicación global del patrimonio cultural. Gijón: Trea, 2008, p. 155-174.

MATLESS, D. Landscape and Englishness. London: Reaktion, 1998.

MITCHELL, D. Landscape and surplus value: The making of the ordinary in
Brentwood, California. Environment and Planning D: Society and Space, $1994 \mathrm{~N}^{\circ} 12$, p. 7-30.

MOILANEN, T. \& RAINISTO, S. How to brand nations, cities and destinations. A planning book for place branding. Basingstoke: Palgrave Macmillan, 2009.

NOGUÉ, J. La construcción social del paisaje. Madrid: Biblioteca Nueva, 2007.

NOGUÉ, J. El paisaje en la cultura contemporánea. Madrid: Biblioteca Nueva, 2008.

NOGuÉ, J. Entre paisajes. Barcelona: Àmbit, 2009.

NOGuÉ, J. \& VICENTE, J. Landscape and national identity in Catalonia. Political Geography, 2004, No 23, p. 113-132.

NORA, P. Les lieux de mémoire. Paris: Gallimard, 1984.

NOUZEILLES, G. La naturaleza en disputa. Retóricas del cuerpo y el paisaje en América Latina. Ciudad de México: Paidós, 2002.

NYE, J. Springing tiger. India Today, 2006, $N^{\circ} 2$, p. 11.

OLINS, W. Wally Olins. On Brand. Madrid: Turner, 2004.

RELPH, E. Place and Placelessness. London: Pion, 1976.

ROGER, A. Court traité du paisaje. Paris: Gallimard, 1997.

RÖSSLER, M. Managing world heritage cultural landscapes and sacred sites. World Heritage Papers, 2003, No 13, p. 45-48.

SCOTT, A. Capitalism, cities and the production of symbolic forms. Transactions of the Institute of British Geographers, 2001, N ${ }^{\circ}$ 26, p. 11-23.

SIMARD, M. Communautés locales et espace-monde. Les processus identitaires de la postmodernité. Géographie et Cultures, 2000, No 36, p. 3-20. 
SOJA, E. Postmodern Geographies: the Reassertion of Space in Critical Social Theory. London: Verso, 1989.

THIEN, D. After or beyond feeling? A consideration of affect and emotion in geography. Area, 2005, No37, p. 450-456.

TUAN, Y. F. Topophilia: a study of environmental perception, attitudes and values. New Jersey: Englewood Cliffs Prentice-Hall, 1974.

TUAN, Y. F. Space and place: the perspective of experience. Minneapolis: University of Minnesota Press, 1977.

VAN HAM, P. Place branding: The state of the art. Annals of the American Academy of Political and Social Science, 2008, № 616, p. 126-149. 